\title{
Korean Version of the Patient Perception of Study Medication Questionnaire: Translation and Linguistic Validation
}

\author{
Tae Jin Kim¹, Kwang Suk Lee², Hyun Kyu Ahn², Jeong Woo Yoo², Kyo Chul Koo² \\ ${ }^{1}$ Department of Urology, CHA Bundang Medical Center, CHA University College of Medicine, Seongnam, Korea \\ ${ }^{2}$ Department of Urology, Gangnam Severance Hospital, Yonsei University College of Medicine, Seoul, Korea
}

\begin{abstract}
Purpose: The patient perception of study medication (PPSM) questionnaire consists of 12 questions designed to quantify patient satisfaction with the efficacy of study treatment by focusing on specific changes that patients experience during the study period. This study aimed to develop a Korean version of the PPSM questionnaire.

Methods: The linguistic validation process consisted of obtaining permission for translation, forward translation, reconciliation, backward translation, cognitive debriefing, and proofreading. Two independent bilingual translators translated the original version of the questionnaire, and a panel discussed and combined the 2 versions. Another independent translator performed backward translation of the reconciled version, after which 15 patients underwent the cognitive debriefing.

Results: The 12 questions and 4 response scales of the PPSM questionnaire were forward translated into 2 Korean versions. The terms were adjusted to conceptually equivalent expressions in Korean. After backward translation, the panel made minor changes to the forward translations for brevity and better readability. No difficulties were experienced during cognitive debriefing by 15 patients, and all items were reported to be generally easy to understand.

Conclusions: The Korean version of the PPSM questionnaire has been successfully translated and validated. The questionnaire is appropriate for assessing symptom satisfaction in patients that undergo benign prostatic hyperplasia pharmacotherapy.
\end{abstract}

Keywords: Patient-Reported Outcomes Measures; Prostatic hyperplasia; Surveys and questionnaires; Translations

- Funding Support: This study was supported by a research grant of the National Research Foundation of Korea (2020R1F1A1073833).

- Research Ethics: This study was approved by the Institutional Review Board of Gangnam Severance Hospital (2017-0615-002).

- Conflict of Interest: No potential conflict of interest relevant to this article was reported.

\section{INTRODUCTION}

Physiologically, with increasing age, the prostate enlarges and can obstruct the prostatic urethra and induce a functional decline of the urethral sphincter. Benign prostatic hyperplasia $(\mathrm{BPH})$ is one of the most common benign neoplasms in the elderly male population, with symptoms reported in approximately half of men by 60 years of age $[1,2]$. Lower urinary tract symptoms (LUTS) such as frequency, incontinence, urgency, and nocturia are due to a combination of $\mathrm{BPH}$ and the anatomical and physiological responses of the bladder to urinary outflow obstruction [3]. Moreover, the progression of BPH with LUTS increases the risk of acute urinary retention (AUR) and decreases maximum urinary flow rate, which ultimately leads to a reduction in patient quality-of-life [4].

Various patient-reported outcome (PRO) questionnaires have been developed to address the increasing need for diseasespecific and validated means to measure PROs to objectively

Corresponding author: Kyo Chul Koo (iD https://orcid.org/0000-0001-7303-6256 Department of Urology, Gangnam Severance Hospital, Yonsei University College of Medicine, 211 Eonju-ro, Gangnam-gu, Seoul 06273, Korea Email: gckoo@yuhs.ac

Submitted: December 23, 2020 / Accepted after revision: February 7, 2021 
analyze and assess BPH with LUTS. In the clinical spectrum of $\mathrm{BPH}$, patient outcome measures such as Boyarsky Score [5], International Prostate Symptom Score (IPSS) [6], and BPH Impact Index (BII) [7] are standard assessment tools. However, these questionnaires show limited efficacy for evaluating treatment satisfaction in patients with BPH. Treatment satisfaction, which includes evaluation of the treatment process and patient outcomes, is rapidly gaining importance in clinical trials and disease-management programs [8,9]. However, the rarity of questionnaires or clinical studies that focus on treatment satisfaction in patients with $\mathrm{BPH}$ indicates a need to develop a valid, reliable treatment satisfaction assessment or questionnaire.

The Patient Perception of Study Medication (PPSM) questionnaire was developed to evaluate the satisfaction levels of $\mathrm{BPH}$ treatments in clinical studies to provide additional insight to clinical practice [10]. The PPSM questionnaire consists of items on the approval levels of the patient for study medication and the patient's final decision after weighing the side effects against the therapeutic advantages and the voluntary compliance in continued administration of the medication [10]. The PPSM questionnaire has been verified to be clinically relevant in several clinical trials $[10,11]$. The objective of this study was to translate the English version of the PPSM questionnaire into Korean, along with consequent linguistic validation in the Korean $\mathrm{BPH}$ patient population.

\section{MATERIALS AND METHODS}

\section{Original PPSM Questionnaire}

The PPSM questionnaire was developed by GlaxoSmithKline (GSK) for use in the CombAT (Combination of Avodart and Tamsulosin) trial to determine whether questions addressing satisfaction with individual symptoms provided additional useful information on patient satisfaction with $\mathrm{BPH}$ pharmacotherapy (Supplementary materials 1-3). The questionnaire consists of 12 questions designed to quantify patient satisfaction with the effect of the study treatment by focusing on specific changes experienced by patients during the study period. The PPSM questionnaire focuses on 4 areas: control of urinary symptoms (2 items), strength of urinary stream ( 2 items), 2 aspects of pain with urination (2 items each), effect on usual activities (2 items), and a single item about overall satisfaction. The final item asks whether the respondent would request a prescription of the study medication.

\section{Permission}

The corresponding author contacted GSK to request permission to translate and utilize a Korean version of the PPSM questionnaire and was responsible for the overall study process.

\section{Translation and Linguistic Validation}

Translation and validation were performed between September and December 2020. The overall study procedure was conceptually similar to previous studies designed to translate non-Korean questionnaires into Korean versions [12,13]. The linguistic validation consisted of forward translation, reconciliation, backward translation, cognitive debriefing, and proofreading.

\section{Forward Translation}

Two bilingual translators who were blinded to the individual translation process independently translated the original version of the PPSM questionnaire into Korean (versions 1.0A and 1.0B). During the process, each translator provided comments and feedback on translation difficulties and various translational options. The IPSS and the Overactive Bladder Symptom Score questionnaires were provided as a reference in unifying medical terminologies regarding voiding symptoms.

\section{Reconciliation}

A panel of 5 urologists and 3 physician assistant nurses reviewed versions $1.0 \mathrm{~A}$ and $1.0 \mathrm{~B}$ and integrated the differences between the 2 versions to create a single new version (ver. 1.1).

\section{Backward Translation}

Version 1.1 was back translated into English by a third independent editor from an English proofreading and editing service. The panel compared the back-translated version with the original version, and alternative translation options were discussed. Discordant phrases were reviewed and revised (ver. 1.2).

\section{Cognitive Debriefing}

The questionnaire (ver. 1.2) was administered to 15 Koreanspeaking patients older than 50 years with different educational backgrounds after informed consent. On completion of the questionnaire, survey interviews were performed by a single certified clinical research coordinator to receive feedback on whether and why there were difficulties in understanding the questions. An opportunity was given to patients to provide alternative phrasing options for better readability and understanding. Based on the interview results, the panel reconvened 
to discuss and agree on a new version (ver. 1.3).

\section{Proofreading}

The final Korean version of the PPSM questionnaire was proofread by the panel for errors in spelling and format.

\section{RESULTS}

\section{Forward Translation and Reconciliation}

The translated 12 questions and 4 response scales of the PPSM questionnaire are presented in Table 1. The "PPSM questionnaire" was translated without disagreement by both translators as yeonguyagmule daehan insig seolmunji.

In question 1, "how has control of your urinary problems changed" was translated as baenyojeungsang-eun eolmana jal jojeoldoego issseubnikka (well controlled) and baenyojeungsangeun eolmana hojeondoeeossseubnikka (improved). "Baenyo" was considered a formal term in the Korean language, and the panel suggested that the usage of "sobyeon" which is a more common Korean term for "urination" would be better approach considering the various education levels of the patient population. Although cognitive feedback showed no difficulties in understanding the question, the panel agreed to the translation usage of sobyeon-eul bol ttaeui bulpyeonham instead of baenyojeungsang for urinary problems.

In question 3, "strength of your urinary stream" was translated to sobyeon julgi (stream) and sobyeon segi (strength). The panel agreed on sobyeon julgi in accordance with the terminology used in the Korean version of the IPSS questionnaire.

In question 9, "how has the way your urinary problems interfere with your ability to go about your usual activities" was translated to ilsangsaenghwal-e yeonghyang-eul juneun jeongdoga eotteohge dallajyeossseubnikka (degree of interference) and ilsangsaenghwal-e michineun yeonghyang-eun eotteohge dallajyeossseubnikka (interference). However, feedback results from the translation showed that "interfere" was not directly mentioned in the Korean translation. The option of "jijang" in as a direct substitute for "interfere" in the Korean version was considered, and question 9 was edited to sobyeon jeungsang-eulo inhae jijangbaddeon ilsangsaenghwal-eun eotteohge dallajyeossseubnikka. The panel discussed differences and agreed on the latter translation considering its brevity and better readability.

The response scale for questions 1, 3, and 9, "much improved; improved; somewhat improved; no change; somewhat worse; worse; much worse/much less control" was translated by both translators without discordance to maeu joh-ajyeossda; johajyeossda; yaggan joh-ajyeossda; byeonhwa-eobsda; yaggan nappajyeossda; maeu nappajyeossda/maeu jojeol-i eolyeobda, respectively.

In questions 2, 4, and 6, "how satisfied are you" was translated to eolmana manjoghasibnikka (how much satisfied) and manjogdoneun eoneu jeongdoibnikka (degree of satisfaction). The panel agreed on eolmana manjoghasibnikka as it is a more familiar and communicative expression in the Korean language. Translations and agreements regarding "the effect of the study medication on control of your urinary problems" in question 2 and "strength of your urinary stream" in question 4 followed the same principle as in questions 1 and 3.

In question 8, "on your pain during urination" was translated to baenyo jung tongjeung (pain during urination) and baenyo tongjeung (urination pain). The panel agreed on sobyeon-eul bol ttae to maintain the nuance of the question.

In question 10, "the effect the study medication has on your ability to go about your usual activities without interference from your urinary problems," was translated to baenyojeungsang-e uihan jijang-eobs-i ilsangjeog-in saenghwal-eul hage haejuneun yeonghyang (ability) and baenyojeungsang-eulo uihan jijang eobs-i ilsangjeog-in saenghwal-eul ganeunghage haejuneun yeonghyang (ability to make it possible). Again, the panel agreed on sobyeon instead of baenyo to maintain the nuance of the question. As a result, the panel discussed and decided on sobyeon jeungsang-eulo inhan jijang-eobs-i ilsangjeog-in hwaldong-eul ganeunghage haejuneun due to better readability.

In question 11, "overall, how satisfied are you with the study medication and its effects on your urinary problems," was translated by both translators without discordance to jeonbanjeog-eulo yeongu yagmulgwa baenyojeungsang-e michineun yeonghyange daehae eolmana manjoghasibnikka. However, the panel again agreed on sobyeonjeungsang instead of baenyojeungsang.

The response scale for questions $2,4,6,8,10$, and 11 , "very satisfied; satisfied; somewhat satisfied; neutral (neither satisfied nor dissatisfied); somewhat dissatisfied; dissatisfied; very dissatisfied," was translated without discordance to maeu manjogseuleobda; manjogseuleobda; yaggan manjogseuleobda; junglib (manjogdo bulmanjogdo anim); yaggan bulmanjogseuleobda; bulmanjogseuleobda; maeu bulmanjogseuleobda.

In questions 5 and 7, "pain prior to urinating" and "pain during urination" was translated to baenyo jeon tongjeung (pain during urination) and to baenyo si tongjeung (pain at urination), respectively. Again, "pain prior to urinating" and "pain during 


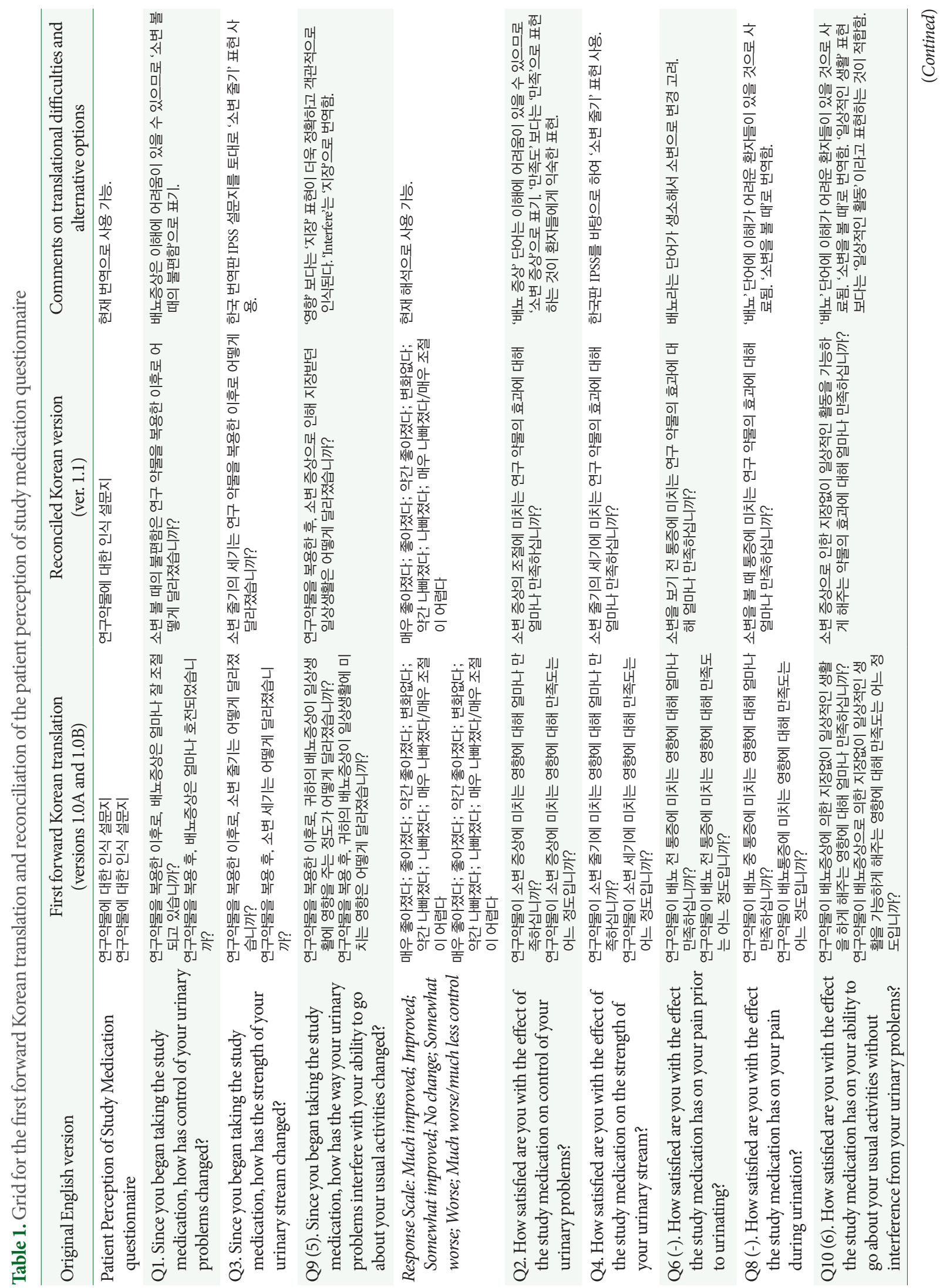




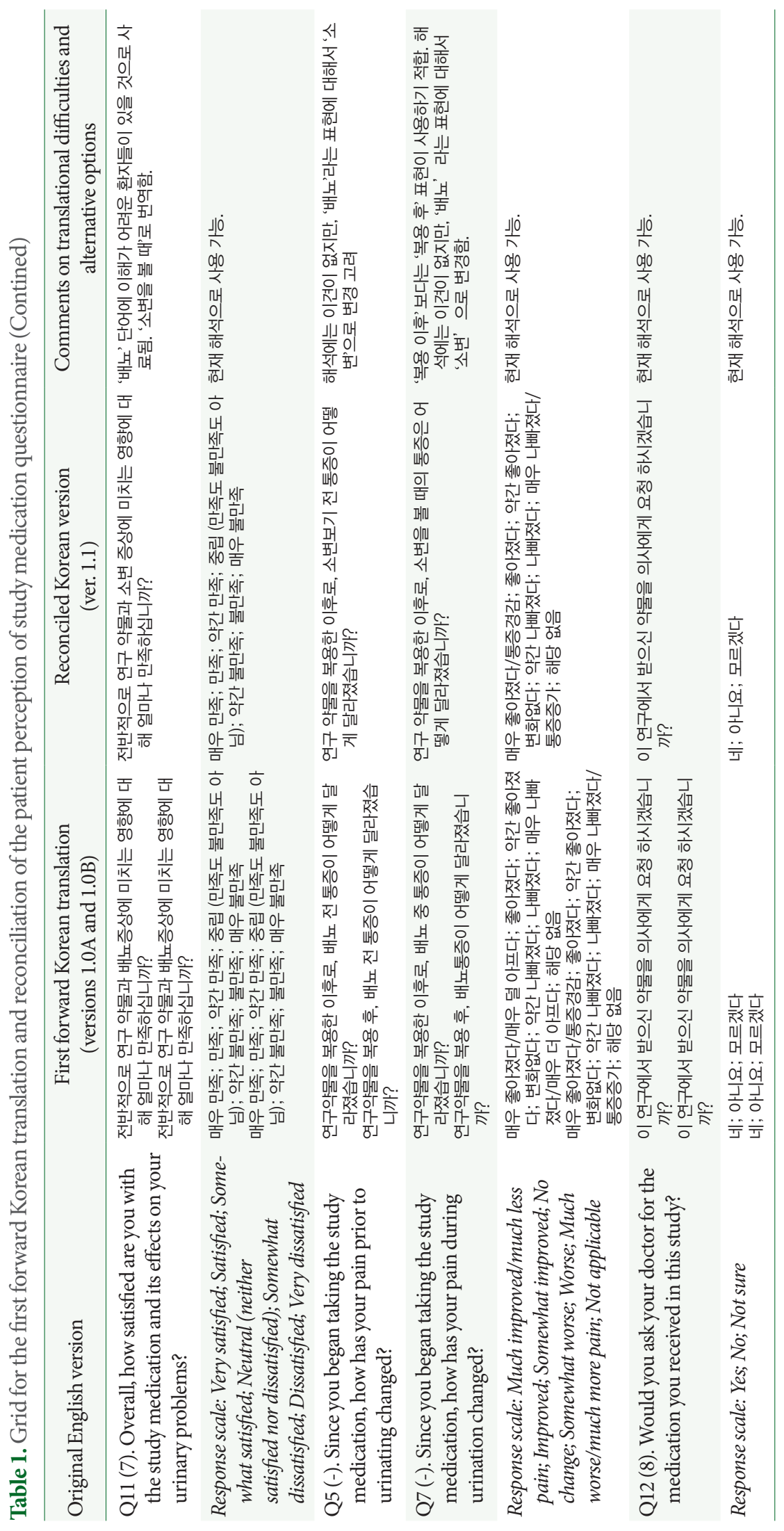


urination" were respectively translated into "sobyun bogee jeon tongjeung" and "sobyun-eul bol ttaeui tongjeung." The translations were based on the same principle as in questions 6 and 8 .

In the response scale for questions 5 and 7, "less pain" and "more pain" were translated to deol apeuda (less pain) and tongjeung-gyeong-gam (pain reduction), and deo apeuda (more pain) and tongjeungjeung-ga (pain escalation), respectively. The panel agreed on tongjeung-gyeong-gam and tongjeung-jeungga for brevity.

In question 12, "would you ask your doctor for the medication you received in this study" and the response scale, "yes; no; not sure," were translated by both translators without discordance to i yeongueseo bad-eusin yagmul-eul uisa-ege yocheong hasigessseubnikka and ne; aniyo; moleugessda, respectively.

\section{Backward Translation and Second Reconciliation}

An independent editor from an English proofreading and editing service performed backward translation of the Korean ver. 1.1 (Table 2). In question 9, "interfere" was backward translated to "influence." In the reconciled version (ver. 1.1), "interfere" was translated into Korean, "yeonghyang." In English, interfere and influence has different meanings. The panels concluded that there were no proper Korean words to represent "interfere" based on the context used in the question. However, after a group panel discussion, the usage of "jijang" as a direct substitute for "interfere" was suggested. Considering the expressions used in the Korean version of the IPSS questionnaire, the panels agreed that this modification was necessary and increased literary fluency.

In questions $1,3,5,7$, and 9, there were discordances in sentence structure involving subject, verb, and object. The panel agreed on the reconciled version for better readability in the Korean language. Otherwise, backward translation of the reconciled version was accepted by all panel members without significant objection.

\section{Cognitive Debriefing}

The translated PPSM questionnaire was administered to $15 \mathrm{Ko}$ rean-speaking male patients who routinely underwent followup in the urology department due to BPH. The median age was 62.5 years (57.0-67.8 years), and the level of education ranged from high school to university degrees. All patients completed the questionnaire within 6 minutes and stated that all items were generally easy to understand. The final version is presented in Fig. 1.

\section{DISCUSSION}

Patient satisfaction is being recognized as a prerequisite to successful outcomes of medical treatment. The 12-item PPSM questionnaire is intended to quantify overall patient satisfaction with the study medication by focusing on specific changes that the patient perceives during the given study period [10]. Our translation and linguistic validation of the PPSM questionnaire support its feasibility as a useful clinical measurement modality for assessing Korean patients with BPH who are undergoing pharmaceutical treatment.

The Korean version of the PPSM questionnaire was translated as closely as possible to the original English version. The translation and validation processes of this study involved complex planning and validation. During the initial forward translation phase, various sections and items of the questionnaire were translated differently in versions 1.0A and 1.0B. Although English and Korean languages have similar sentence structures and share words that convey the same meaning, the variation in expression of context and nuances results in discrepancies in the exact wording of the translation. Alterations in translations between the 2 translators were noted. In the forward translation stage, discrepancies between the 2 translators included the following terms: "urinary control" in question 1 , "urinary stream" in question 3, and "interfere" in question 9, while slight differences were noted in the translation of "satisfaction" in items 2, 4, and 8.

After analyzing the backward translation through a panel discussion during the reconciliation phase, the discrepancies between version $1.0 \mathrm{~A}$ and $1.0 \mathrm{~B}$ were reduced in the reconciled Korean translation of the PPSM. The panels concluded that there were no substitute Korean words to represent "interfere" in the proper context used in the English version. The terminology in the Korean version of the IPSS questionnaire was used as a reference, and the panel agreed that paraphrasing "interfere" into "influence" was adequate for the questionnaire [14].

Measuring patient satisfaction with medication from the perspective of the patient based on experience and willingness to ask the physician for continued treatment provides valuable clinical information. The importance of assessing PROs, along with objective clinical parameters, is recognized by the U.S. Food and Drug Administration (FDA) [15] and recommended in various clinical practice guidelines for managing $\mathrm{BPH}$ patients $[16,17]$. Subjective outcome measures such as BII are extensively used to assess the efficacy of interventions for $\mathrm{BPH}$ 


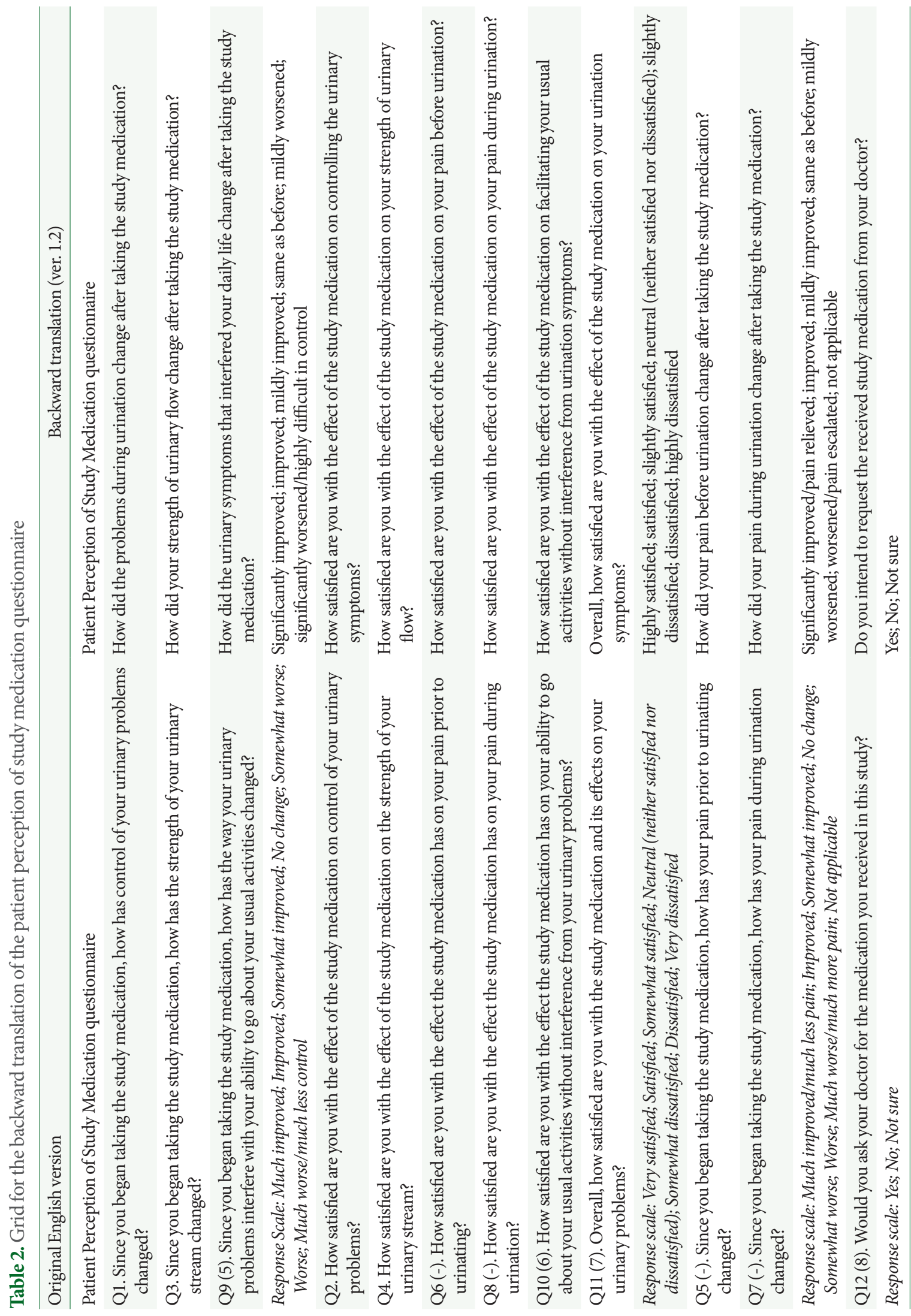


연구약물에 대한 인식 설문지

\begin{tabular}{|c|c|c|c|c|c|c|c|c|}
\hline 질문 1 & 매우 좋아졌다 & 좋아졌다 & 약간 좋아졌다 & 변화없다 & 약간 나빠졌다 & 나빠졌다 & $\begin{array}{c}\text { 매우 나ㅃㅏㅉㅆㅆㄷㅏ/ } \\
\text { 매우 조절이 엽담 }\end{array}$ & \\
\hline $\begin{array}{l}\text { 소변 볼 때의 불편함은 연구 약물을 복용한 } \\
\text { 이후로 어떻ㅎㄱㅔ 달라졌습니까? }\end{array}$ & $\square$ & $\square$ & $\square$ & $\square$ & $\square$ & $\square$ & $\square$ & \\
\hline 질문 2 & 매우 만족 & 만족 & 약간 만족 & $\begin{array}{c}\text { 중립 } \\
\text { (만족도 불만족도 아님) } \\
\end{array}$ & 약간 불만족 & 불만족 & 매우 불만족 & \\
\hline $\begin{array}{l}\text { 소변 증상의 조절에 미치는 연구 약물의 효 } \\
\text { 과에 대해 얼마나 만족하십니까? }\end{array}$ & $\square$ & $\square$ & $\square$ & $\square$ & $\square$ & $\square$ & $\square$ & \\
\hline 질문 3 & 매우 줗아졌다 & 좋아젔다 & 약간 줗아젔다 & 변화없다 & 약간 나빠졌다 & 나빠젔다 & $\begin{array}{c}\text { 매우 나빠젔다/ } \\
\text { 매우 조절이 어렵다 }\end{array}$ & \\
\hline $\begin{array}{l}\text { 소변 줄기의 세기는 연구 약물을 복용한 이 } \\
\text { 후로 어뗳게 달라졌습니까? }\end{array}$ & $\square$ & $\square$ & 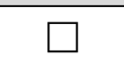 & $\square$ & $\square$ & $\square$ & $\square$ & \\
\hline 질문 4 & 매우 만족 & 만족 & 약간 만족 & $\begin{array}{c}\text { 중립 } \\
\text { (만족도 불만족도 아님) }\end{array}$ & 약간 불만족 & 불만족 & 매우 불만족 & \\
\hline $\begin{array}{l}\text { 소변 줄기의 세기에 미치는 연구 약물의 효 } \\
\text { 과에 대해 얼마나 만족하십니까? }\end{array}$ & $\square$ & $\square$ & & $\square$ & $\square$ & $\square$ & $\square$ & \\
\hline 질문 5 & $\begin{array}{l}\text { 매우 좋아졌다/ } \\
\text { 매우 덜 아프다 }\end{array}$ & 좋아젔다 & 약간 좋아졌다 & 변화없다 & 약간 나빠젔다 & 나빠졌다 & $\begin{array}{l}\text { 매우 나빠젔다매우 } \\
\text { 더 아프다 }\end{array}$ & 해당없음 \\
\hline $\begin{array}{l}\text { 연구 약물을 복용한 이후로, 소변보기전 } \\
\text { 종응이 어떻게 달라졌습니까? }\end{array}$ & $\square$ & $\square$ & $\square$ & $\square$ & $\square$ & $\square$ & $\square$ & 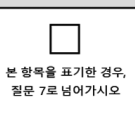 \\
\hline 질문 6 & 매우 만족 & 만족 & 약간 만족 & $\begin{array}{c}\text { 중립 } \\
\text { (만족도 불만족도 아님) } \\
\end{array}$ & 약간 불만족 & 물만족 & 매우 불만족 & \\
\hline $\begin{array}{l}\text { 소변을 보기 전 통증에 미치는 연구 약물의 } \\
\text { 효과에 대해 얼마나 만족하십니까? }\end{array}$ & $\square$ & $\square$ & $\square$ & $\square$ & $\square$ & $\square$ & $\square$ & \\
\hline 질문 7 & $\begin{array}{l}\text { 매우 종아젔다/ } \\
\text { 매우 덜 아프다 }\end{array}$ & 좋아젔다 & 약간 좋아젔다 & 변화없다 & 약간 나빠젔다 & 나빠젔다 & $\begin{array}{c}\text { 매우 나빠젔다/매우 } \\
\text { 더 아프다 }\end{array}$ & 해당 없음 \\
\hline $\begin{array}{l}\text { 연구 약물을 복용한 이후로, 소변을 볼때 } \\
\text { 의 통증은 어떻게 달라졌습니까? }\end{array}$ & $\square$ & $\square$ & $\square$ & $\square$ & $\square$ & $\square$ & $\square$ & 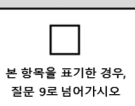 \\
\hline 질문 8 & 매우 만족 & 만족 & 약간 만족 & $\begin{array}{c}\text { 중립 } \\
\text { (만족도 불만족도 아님) }\end{array}$ & 약간 불만족 & 불만족 & 매우 불만족 & \\
\hline $\begin{array}{l}\text { 소변을 볼 때 통증에 미치는 연구 약물의 } \\
\text { 효과에 대해 얼마나 만족하십니까? }\end{array}$ & $\square$ & $\square$ & $\square$ & $\square$ & $\square$ & $\square$ & $\square$ & \\
\hline 질문 9 & 매우 줗아졌다 & 줗아젔다 & 약간 좋아졌다 & 변화없다 & 약간 나빠젔다 & 나빠졌다 & \begin{tabular}{c|} 
매우 나빠젔다/ \\
매우 조절이 어렵다
\end{tabular} & \\
\hline $\begin{array}{l}\text { 연구약물을 복용한 후, 소변 증상으로 인해 } \\
\text { 지장받던 일생ㅇㅎㄹ는 어떻게 달라졌습니 } \\
\text { 까? }\end{array}$ & $\square$ & $\square$ & $\square$ & $\square$ & $\square$ & $\square$ & $\square$ & \\
\hline 질문 10 & 매우 만족 & 만족 & 약간 만족 & $\begin{array}{c}\text { 중립 } \\
\text { (만족도 불만족도 아님) }\end{array}$ & 약간 불만족 & 불만족 & 매우 불만족 & \\
\hline $\begin{array}{l}\text { 소변 증상으로 인한 지장없이 일상적인활 } \\
\text { 동을 가능하게 해주는 약물의 효과에 대해 } \\
\text { 멀마나 만족하십니까? }\end{array}$ & $\square$ & $\square$ & $\square$ & $\square$ & $\square$ & $\square$ & $\square$ & \\
\hline 질문 11 & 매우 만족 & 만족 & 약간 만족 & $\begin{array}{c}\text { 중립 } \\
\text { (만족도 불만족도 아님) }\end{array}$ & 약간 불만족 & 불만족 & 매우 불만족 & \\
\hline $\begin{array}{l}\text { 전반적으로 연구 약물과 소변 증상에미치 } \\
\text { 영향에 대해 얼마나 만족하십니까? }\end{array}$ & $\square$ & $\square$ & $\square$ & $\square$ & $\square$ & $\square$ & $\square$ & \\
\hline 질문 12 & 네 & 아니요 & 모르겠음 & & & & & \\
\hline $\begin{array}{l}\text { 이 연구에서 받으신 약물을 의사에게요청 } \\
\text { 하시겠습니까? }\end{array}$ & $\square$ & $\square$ & $\square$ & & & & & \\
\hline
\end{tabular}

Fig. 1. Final Korean version of the patient perception of study medication questionnaire. 
with LUTS [7]. However, the relationships between the change in outcome scores and patient perception and satisfaction with change have not been well studied [18]. Therefore, the main objective of our study was to implement a questionnaire that includes relevant items and domains that are necessary for assessing treatment satisfaction in the Korean population. After translation and reconciliation of the original PPSM questionnaire, the Korean version was verified for validity and suitability for usage in the clinical setting. However, the differences in English and Korean expressions had to be adjusted based on cultural context and language nuances, and appropriate modifications were made to improve the implied nuances and relevance suitable to Korean culture. Another limitation of the study was the small number of participants in the study population; therefore, the need for future larger-scale studies is warranted to assess and confirm the reliability and validity of the Korean version. Nevertheless, this study suggests that the Korean translation version of the PPSM questionnaire is a relevant work tool that can be used in the clinical field to evaluate patients with BPH with LUTS.

Based on the results and patient feedback, this study suggests that the Korean translation version of the PPSM questionnaire is a relevant tool that can be used in the clinic to evaluate patients with BPH and LUTS.

\section{SUPPLEMENTARY MATERIALS}

Supplementary materials 1-3 can be found via https://oi.org/ 10.5213/inj.2040476.238. Supplementary material 1. Interview Form. Supplementary material 2. Patient Perception of Study Medication. Supplementary material 3. Cognitive debriefing.

\section{AUTHOR CONTRIBUTION STATEMENT}

- Conceptualization: KCK

- Data curation: KSL, HKA, JWY

- Formal analysis: TJK

- Funding acquisition: $K C K$

- Methodology: TJK, KCK

- Project administration: KCK

- Visualization: $K C K$

- Writing-original draft: TJK, KCK

-Writing-review \& editing: TJK, KCK

\section{ORCID}

$\begin{array}{ll}\text { Tae Jin Kim } & 0000-0001-7836-1998 \\ \text { Kwang Suk Lee } & 0000-0002-7961-8393 \\ \text { Hyun Kyu Ahn } & 0000-0002-1996-6249 \\ \text { Jeong Woo Yoo } & 0000-0002-0488-3598 \\ \text { Kyo Chul Koo } & 0000-0001-7303-6256\end{array}$

\section{REFERENCES}

1. Kim DK, Park JJ, Yang WJ, Doo SW, Kim JH, Song YS. Changes in diagnosis rate and treatment trends of benign prostatic hyperplasia in Korea: a nationwide population-based cohort study. Prostate Int 2021;9:215-20.

2. Kim TH, Han DH, Ryu DS, Lee K. The Impact of Lower Urinary Tract Symptoms on quality of life, work productivity, depressive symptoms, and sexuality in korean men aged 40 years and older: a population-based survey. Int Neurourol J 2015;19:120-9.

3. McConnell JD, Bruskewitz R, Walsh P, Andriole G, Lieber M, Holtgrewe HK, et al. The effect of finasteride on the risk of acute urinary retention and the need for surgical treatment among men with benign prostatic hyperplasia. Finasteride Long-Term Efficacy and Safety Study Group. N Engl J Med 1998;26:557-63.

4. Donnell RF. Benign prostate hyperplasia: a review of the year's progress from bench to clinic. Curr Opin Urol 2011;21:22-6.

5. Boyarsky S, Jones G, Paulson DF, Prout GR Jr. A new look at bladder neck obstruction by the food and drug administration regulators: guide lines for investigation of benign prostatic hypertrophy. Trans Am Assoc Genitourin Surg 1976;68:29-32.

6. Barry MJ, Fowler FJ Jr, O'Leary MP, Bruskewitz RC, Holtgrewe HL, Mebust WK, et al. The American Urological Association symptom index for benign prostatic hyperplasia. The Measurement Committee of the American Urological Association. J Urol 1992;148: 1549-57.

7. Barry MJ, Fowler FJ Jr, O'Leary MP, Bruskewitz RC, Holtgrewe HL, Mebust WK. Measuring disease-specific health status in men with benign prostatic hyperplasia. Measurement Committee of The American Urological Association. Med Care 1995;33:AS145-55.

8. Shikiar R, Rentz AM. Satisfaction with medication: an overview of conceptual, methodologic, and regulatory issues. Value Health 2004; 7:204-15.

9. Weaver M, Patrick DL, Markson LE, Martin D, Frederic I, Berger M. Issues in the measurement of satisfaction with treatment. Am J Manag Care 1997;3:579-94.

10. Black L, Grove A, Morrill B. The psychometric validation of a US 
English satisfaction measure for patients with benign prostatic hyperplasia and lower urinary tract symptoms. Health Qual Life Outcomes 2009;7:55.

11. Roehrborn CG, Siami P, Barkin J, Damião R, Major-Walker K, Nandy I, et al. The effects of combination therapy with dutasteride and tamsulosin on clinical outcomes in men with symptomatic benign prostatic hyperplasia: 4-year results from the CombAT study. Eur Urol 2010;57:123-31.

12. Jeong SJ, Homma Y, Oh SJ. Korean version of the overactive bladder symptom score questionnaire: translation and linguistic validation. Int Neurourol J 2011;15:135-42.

13. Kang SH, Oh SJ, Jeong SJ, Cho SY. Linguistic validation of the intermittent self-catheterization questionnaire for patients with neurogenic bladder who perform intermittent catheterization for voiding dysfunction. Int Neurourol J 2019;23:75-85.

14. Kim JH, Doo SW, Yang WJ, Song YS. Homogeneity among the korean international prostate symptom score questionnaires used in real practice. Korean J Urol 2013;54:249-51.

15. U.S. Department of Health and Human Services FDA Center for
Drug Evaluation and Research; U.S. Department of Health and Human Services FDA Center for Biologics Evaluation and Research; U.S. Department of Health and Human Services FDA Center for Devices and Radiological Health. Guidance for industry: Patient-Reported Outcome Measures: use in medical product development to support labeling claims: draft guidance. Health Qual Life Outcomes 2006;4:79.

16. AUA Practice Guidelines Committee. AUA guideline on management of benign prostatic hyperplasia (2003). Chapter 1: Diagnosis and treatment recommendations. J Urol 2003;170:530-47.

17. Gratzke C, Bachmann A, Descazeaud A, Drake MJ, Madersbacher $S$, Mamoulakis, et al. EAU guidelines on the assessment of nonneurogenic male lower urinary tract symptoms including benign prostatic obstruction. Eur Urol 2015;67:1099-109.

18. Suh J, Oh SJ, Cho SY. Comprehensive review of effective application of questionnaires for clinical research on lower urinary tract symptoms with translation and cultural adaptation to the Korean language. Int Neurourol J 2020;24:313-23. 